\title{
Why Deteriorating Relations, Xenophobia, and Safety Concerns Will Deter Chinese International Student Mobility to the United States
}

\author{
Ryan M. Allen \\ Chapman University, USA \\ Ying Ye \\ Shanghai Normal University, China
}

\begin{abstract}
Collaborations between American and Chinese universities have been critical to global knowledge production. Chinese students accounted for over a third of all international students in the United States prior to COVID-19, but the pandemic paused most global mobility in 2020 . We argue that this international mobility to the United States will not fully recover if larger stressors are left unaddressed. First, relations between the United States and China have deteriorated in recent years, especially under the Trump administration, with growing suspicion against Chinese researchers and scholars. Second, viral acts of violence and anti-Asian incidents have painted the United States as unsafe for Chinese students. Finally, given the mismanaged response to the pandemic, it may take years before trust returns from abroad. While the Biden administration has promised to curb some of these issues, the perceptions of the United States may have been permanently altered, especially as China has improved its domestic higher education sector in recent years.
\end{abstract}

Keywords: Chinese students, COVID-19, student mobility, xenophobia 


\section{INTRODUCTION}

China is the largest sender of international students to the United States, accounting for over 372,000 students in the academic year before COVID-19 hit (Institute of International Education, 2020). This means that roughly one out of every three international students studying on American campuses came from China, contributing over $\$ 15$ billion to the U.S. economy every year (Malden \& Stephens, 2020). Lee and Haupt (2019) showed that collaborative research by American and Chinese scientists has dramatically risen in recent decades, while Evans et al. (2020) argued that joint research efforts will need to be amped up to stave off the next global pandemic. Due to the level of engagement, the relationship between China and the United States is the most consequential for the American higher education sector. But the relationship has been threatened in recent years due to a variety of reasons, and not only because of the pause in global mobility related to COVID-19.

One weekend defined a culmination of these larger issues in the relationship. On the weekend after January 9, 2021, Americans, still locked in quarantine for almost a year, were reeling from the shocking footage of rioting and insurrection at the nation's capitol building. The images also shocked people in China, but attention that weekend was centered on Yiran Fan, a Chinese international student murdered in Chicago during a random rampage in the city. Together these events highlighted the poor management of the COVID-19 crisis, disgraceful imagery of riots, and tangible threats of gun violence - reinforcing the idea that the United States is dangerous, unpredictable, and unwelcoming - not exactly an ideal location to study for international students.

The election of Donald Trump was particularly damaging to international higher education in the United States, with the Muslim ban, increased vetting of student visas, and general antiforeigner rhetoric. Rose-Redwood and RoseRedwood (2017) said that the "travel ban had the effect of undermining this core mission of higher education" (p. iii). While many hoped that the Biden administration could reset the sector, the lingering effects stemming from Trump and other controversies cannot be easily mended, particularly with China. In this commentary, we argue that international student engagement will not fully recover from the pause in mobility due to the pandemic if these larger stressors are left unaddressed.

\section{U.S.-China Relations}

Trump campaigned on taking a harder stance against China and enacted a series of targeted policies against the nation, such as tariffs on certain goods. At one point, Trump even considered banning Chinese students from coming to American universities, but eventually decided against the measure (Sevastopulo \& Mitchell, 2018). However, the administration did add restrictions to some graduate students and canceled visas for roughly 1,000 students and researchers with reported connections to the military (Mervis, 2018). These reactions were part of growing distrust toward Chinese scientists and researchers, with loud 
accusations of spying. Even before Trump, Confucius Institutes had been continually targeted by American policymakers as a kind of catch-all boogeyman for espionage. Headlines have been made about researchers being arrested for hiding their inclusion with China's Thousand Talents Plan when receiving federal government grants. In some cases, though, missing from the conversation was that the researchers also did not disclose programs with other countries like South Korea or Japan (U.S. Department of Justice, 2021).

Exacerbated by the Trump administration's rhetoric, the sentiments only worsened with the global outbreak of COVID-19. When the pandemic began, Trump blamed China for failing to contain the virus early on, insisting on calling it the "Chinese virus" and demanding that the Chinese government "pay a big price" for letting it happen (as quoted by Walsh, 2020). Devlin et al. (2020) reported that during the height of the pandemic, Americans' unfavorable views of China reached record levels. Tangibly throughout the lockdown, anger and suspicion boiled over with a spike in racist and xenophobic attacks against Chinese people or other Asians mistaken for Chinese, which were only fueled by bombastic rhetoric from the Trump administration and other U.S. officials. In this environment, Chinese students have faced increased scrutiny at U.S. airports, been labeled as technology thieves, and harassed due to national origin.

\section{Safety}

Safety has been a concern for international students in the United States (Nicholls, 2018). Uncertainties and distance breeds anxieties, and the ubiquity of guns and high-profile shootings have undoubtedly shaped students' and parents' perceptions of security in American schools. But cameras and smartphones have inundated feeds with images and news of violence like never before, bolstering fears that have been prevalent in the past. Now, protesters and even rioters routinely livestream or post to social media, which is viewed across the world, sometimes losing important contextual information. For instance, the summer protests of 2020 were bookended by the riots at the Capitol, sending the signal that the United States is not only dangerous but also unstable. Even if these incidents were isolated or focused, the viral nature of the imagery puts them in the palm of every parent with a child studying abroad.

These threats are exacerbated for Chinese students due to the anti-Chinese sentiments rising in recent years on and around campuses (Ma, 2020). While apparently random, the death of Yiren Fan at the University of Chicago only made these images all too real for prospective international students. Furthermore, there have been other hate crimes against Asian Americans stemming from misplaced xenophobia connected to China. These events and others like it, such as the Atlanta spa shooting, have made violence against Asians a salient issue. It is easy to understand how Chinese parents or students would ask: What if that was me? What if my son got caught in a riot? How can I know my daughter will be safe? Even if American campuses are generally safe, there is a sense that the entire United States is dangerous. Students and parents feel their safety could be at risk 
at any time. Under such circumstances, we wonder how many Chinese parents would agree to send their children to study under such conditions.

\section{Handling of COVID-19}

The mismanagement of COVID-19 in the United States has led to a staggering number of deaths and an elongated pandemic. The world has noticed. People in China have watched the reckless, inept approach that American leaders have taken in dealing with the virus and could only compare to the coordinated, serious efforts by their own government. The clips of antimask protests or public freak-outs against basic precautions were not isolated to the internet in the United States; they have been shared and mocked on WeChat and other social media. In contrast, China took the most stringent prevention and control measures to prevent the spread of the epidemic. Residents were required to wear masks in public places, lockdowns were enforced, and contract tracing/testing was implemented nationally. Wuhan, Hubei province in China, where the epidemic situation was the most severe, returned to some normalcy after a few months of lockdown. People there were allowed to leave the city if they held a green health code, meaning no contact with any infected or suspected COVID-19 cases. It is because of such an aggressive response that hundreds of thousands of people in China were prevented from contracting the virus. Even with the vaccine rollout underway, the comparative death tolls in the United States have been staggering.

\section{MOVING FORWARD}

Given the importance of this relationship, American universities must work to gain back the trust of Chinese students, and much of this work must go beyond singular institutions. The rollout of the vaccine is a major test for the United States in the eyes of the world. Many stakeholders are hoping for a return to some normalcy by the Fall 2021 semester, unpausing the global mobility freeze. Given the last year, though, there are still those who will remain skeptical, and it may take years before that trust returns from abroad. If society does open back up, some of the unrest may subside. Likewise, the Biden administration has already shown a more subdued approach to the presidency, which should be felt by other people around the world. While some incidents will always occur, the shocking and unprecedented scenes from the last year could make way for calmer imagery.

Similarly, Biden has already released a Presidential Memorandum order condemning the anti-Asian sentiments that plagued most of 2020 and beyond ("Condemning and Combating Racism," 2021). While he hasn't promised to reverse all of Trump's policies, the bombastic and unpredictable approach to foreign policy from the previous president has been halted by Biden. However, there are still many officials hawkish on China, such as Republican Senator Tom Cotton, who recently proposed a new ban on Chinese students in certain STEM areas, more intense visa vetting, and the severance of ties with Chinese universities nationally (Cotton, 2021). Even Biden's nominee for CIA director, William J. Burns, suggested that universities should cut ties with Confucius 
Institutes in his Senate hearing (CBS News, 2021). This kind of mistrust from the highest levels trickles down to students and individuals.

Unfortunately, some efforts might be too late, as the image of the United States in China has likely been permanently altered. Chinese students are already taking seriously other locales around the world with friendlier policies, perceived safer environments, and better handling of COVID-19. Furthermore, China's own domestic sector has rapidly improved in terms of international standing in recent years (Allen, 2017). While capacity issues have been a problem, the central government has recently mandated more seats for students in master's programs in Chinese universities (Wang, 2021). Likewise, policymakers have also made efforts to improve various parts of the sector, such as the Teacher Professional Development Center in Shanghai Normal University, a program targeted at improving the quality of private higher education in Shanghai.

Educators did have similar concerns after the attacks on $9 / 11$ precipitated drops in foreign students, but the worries proved to be misplaced and the sector rebounded to record gains only a few years later. However, much of those gains were made from increased Chinese student intake. If the sector hopes to maintain and thrive after COVID-19, the larger relationship between the United States and China must be mended. Stories like Yiran Fan or other viral acts of violence or xenophobia, along with a bombastic foreign policy, will only continue the descent. American higher education certainly did not cause these issues, but the sector will face the brunt of their consequences.

\section{REFERENCES}

Allen, R. M. (2017). A comparison of China's "Ivy League" to other peer groupings through global university rankings. Journal of Studies in International Education, 21(5), 395-411.

CBS News. (2021, February 24). CIA director nominee William Burns questioned at Senate confirmation hearing [Video]. Youtube. https://www.youtube.com/watch?t=4568\&v=smHNSwt9B0M\&feature=you tu.be

Condemning and combating racism, xenophobia, and intolerance against Asian Americans and Pacific Islanders in the United States, Presidential Memorandum, No. 2021-02073, 86 FR 7485. (2021, January 26). https://www.federalregister.gov/documents/2021/01/29/202102073/condemning-and-combating-racism-xenophobia-and-intoleranceagainst-asian-americans-and-pacific

Cotton, T. (2021). Beat China: Targeted decoupling and the economic long war. Office of Senator Tom Cotton. https://www.cotton.senate.gov/imo/media/doc/210216_1700_China\%20Rep ort_FINAL.pdf?utm_campaign=latitude $\% 28 \mathrm{~s} \% 29 \& u u_{m}$ _medium $=$ email\&ut $m \_$source $=$Revue $\% 20$ newsletter

Devlin, K., Silver, L., \& Huang, C. (2020, April 21). U.S. views of China increasingly negative amid Coronavirus outbreak. Pew Research Center. 
https://www.pewresearch.org/global/2020/04/21/u-s-views-of-chinaincreasingly-negative-amid-coronavirus-outbreak/.

Evans, T. S., Shi, Z., Boots, M., Liu, W., Olival, K. J., Xiao, X., Vandewoude, S., Brown, H., Chen, J.-L., Civitell, D. J., Escobar, L., Grohn, Y., Li, H., Lips, K., Liu, Q., Lu, J., Martinez-Lopez, B., Shi, J., Shi, X., ... Getz, W. M. (2020). Synergistic China-US ecological research is essential for global emerging infectious disease preparedness. EcoHealth, 17(1), 160-173.

Institute of International Education. (2020). Open Doors fast facts 2020. https://opendoorsdata.org/fast_facts/fast-facts-2020/

Lee, J. J., \& Haupt, J. P. (2019). Winners and losers in US-China scientific research collaborations. Higher Education, 80, 57-74.

Ma, Y. (2020). Ambitious and anxious: How Chinese college students succeed and struggle in American higher education. Columbia University Press.

Malden, K., \& Stephens, S. (2020). Cascading economic impacts of the COVID19 outbreak in China [Staff Research Report]. US-China Economic and Security Review

Commission. https:/www.uscc.gov/sites/default/files/2020-

04/Cascading_Economic_Impacts_of_the_Novel_Coronavirus_April_21_2 020.pdf

Mervis, J. (2018, June 11). More restrictive US policy on Chinese graduate student visas raises alarm. Science. doi:10.1126/science.aau4407

Nicholls, S. (2018). Influences on international student choice of study destination: Evidence from the United States. Journal of International Students, 8(2), 597-622.

Rose-Redwood, C., \& Rose-Redwood, R. (2017). Rethinking the politics of the international student experience in the age of Trump. Journal of International Students, 7(3), i-ix.

Sevastopulo, D., \& Mitchell, T. (2018). US considered ban on student visas for Chinese nationals. Financial Times. https://www.ft.com/content/fc413158c5f1-11e8-82bf-ab93d0a9b321

U.S. Department of Justice (2021). Senior NASA scientist pleads guilty to making false statements related to Chinese Thousand Talents Program participation and professorship. U.S. Attorney's Office, Southern District of New York. https://www.justice.gov/usao-sdny/pr/senior-nasa-scientist-pleads-guiltymaking-false-statements-related-chinese-thousand

Walsh, J. (2020, October 8). Trump is demanding China pay 'big price' for Covid19. Forbes. https://www.forbes.com/sites/joewalsh/2020/10/08/trump-isdemanding-china-pay-big-price-for-covid-19/?sh=5c6fc $77 \mathrm{c} 41 \mathrm{c} 8$

Wang, V. (2021, January 18). China's college graduates can't find jobs. The solution: Grad school. The New York Times. https:/www.nytimes.com/2021/01/18/business/china-graduate-schoolwhite-collar.html

RYAN M. ALLEN, PhD, is an assistant professor at Chapman University's Donna Ford Attallah College of Educational Studies. He primarily works with the 
college's doctoral program partnered with Shanghai Normal University. His research focuses on internationalizations of higher education, EdTech, academic publishing, and the East Asian region. He serves on the executive board of the Study Abroad and International Student SIG within the Comparative and International Education Society, where he shares his passion for supporting global mobility and promoting study abroad. Email: ryallen@chapman.edu

YING YE, EdD, is a faculty in the School of Education of Shanghai Normal University, mainly responsible for the international programs. She received her doctoral degree from East Normal University in China, majoring in Education Leadership. She has also been exploring how international collaboration and communication can be established between universities from different countries in terms of both research and practice. Email: yeying@shnu.edu.cn 